\title{
SEEING RED
}

\section{HIV / AIDS and Public Policy in Canada}

What does it mean to think of HIV / AIDS policy in a critical manner? Seeing Red offers the first critical analysis of HIV / AIDS policy in Canada. Featuring the diverse experiences of people living with HIV, this collection highlights various perspectives from academics, activists, and community workers who look ahead to the new and complex challenges associated with HIV / AIDS and Canadian society.

In addition to representing a diversity of voices and perspectives, Seeing Red reflects on historical responses to HIV/AIDS in Canada. Among the specific issues addressed are the over-representation of Indigenous peoples among those living with HIV, the criminalization of $\mathrm{HIV}$, and barriers to health and support services, particularly as experienced by vulnerable and marginalized populations. The editors and contributors seek to show that Canada has been neither uniquely compassionate nor proactive when it comes to supporting those living with HIV / AIDS. Instead, this remains a critical area of public policy, one fraught with challenges as well as possibilities.

SUZANNE HINDMARCH is assistant professor of Political Science at the University of New Brunswick.

Michael orsini is professor in the School of Political Studies at the University of Ottawa.

MARILOU GAGNON is associate professor at the School of Nursing in the Faculty of Health Sciences at the University of Ottawa. 
This page intentionally left blank 


\title{
Seeing Red
}

HIV/AIDS and Public Policy in Canada

\author{
EDITED BY SUZANNE HINDMARCH, \\ MICHAEL ORSINI, AND MARILOU GAGNON
}

UNIVERSITY OF TORONTO PRESS

Toronto Buffalo London 
(C) University of Toronto Press 2018

Toronto Buffalo London

utorontopress.com

Printed in Canada

ISBN 978-1-4875-0015-3 (cloth)

ISBN 978-1-4875-2009-0 (paper)

( Printed on acid-free, $100 \%$ post-consumer recycled paper

with vegetable-based inks.

\section{Library and Archives Canada Cataloguing in Publication}

Seeing red : HIV / AIDS and public policy in Canada/edited by Suzanne Hindmarch, Michael Orsini, and Marilou Gagnon.

Includes bibliographical references and index.

ISBN 978-1-4875-0015-3 (cloth). - ISBN 978-1-4875-2009-0 (paper)

1. AIDS (Disease) - Government policy - Canada. 2. AIDS (Disease) Patients - Services for - Canada. 3. AIDS (Disease) - Patients - Canada Social conditions. 4. Canada-Public policy. I. Hindmarch, Suzanne, 1975-, editor II. Orsini, Michael, 1967-, editor III. Gagnon, Marilou, 1980-, editor

RA643.86.C3S44 2018 362.19697'9200971 C2017-906336-7

This book has been published with the help of a grant from the Federation for the Humanities and Social Sciences, through the Awards to Scholarly Publications Program, using funds provided by the Social Sciences and Humanities Research Council of Canada.

University of Toronto Press acknowledges the financial assistance to its publishing program of the Canada Council for the Arts and the Ontario Arts Council, an agency of the Government of Ontario.

Canada Council for the Arts
Conseil des Arts du Canada
ONTARIO ARTS COUNCIL CONSEIL DES ARTS DE L'ONTARIO

an Ontario government agency un organisme du gouvernement de I'Ontario

\footnotetext{
Funded by the Financé par le Government gouvernement of Canada du Canada 